\title{
THE HOODED MERGANSER.
}

\author{
-Mergus cucullatus, Linn.
}

\section{PLATE CCCCXIII.-MaLe and Female.}

Excepting the Smew or White Nun, the Hooded Merganser is the handsomest of its family. Its broad and rounded crest of pure white, with an edging of jetty black, and which it closes or spreads out at pleasure, renders the male of this species conspicuous on the waters to which it resorts. The activity of its motions, the rapidity of its flight, and its other habits, contribute to render it a pleasing object to the student of nature, not less than to the sportsman. Its flesh, however, has a fishy taste and odour, although it is relished by some persons. It seems to prefer fresh water, and is by no means very frequent along the sea coast. Long, narrow, and moderately deep creeks, or small ponds, are more frequented by it than large rivers or lakes.

On the waters of the Western and Southern States, these Mergansers are seen to arrive from the north early in October, but generally later than many species of Ducks, although sooner than either the Red-breasted Merganser or the Goosander. At the approach of night, a person standing still on the banks of such a river as the Ohio, first hears the well-known sound of wings whistling through the air, presently after, a different noise, as if produced by an Eagle stooping on her prey, when gliding downwards with the rapidity of an arrow, he dimly perceives the Hooded Mergansers sweeping past. Five or six, perhaps ten, there are; with quick beats of their pinions, they fly low over the waters in wide circles. Now they have spied the entrance of a creek; there they shoot into it, and in a few seconds you hear the rushing noise which they make as they alight on the bosom of the still pool. How often have I enjoyed such scenes, when enticed abroad by the clear light of the silvery moon, I have wandered on the shores of la belle rivière, to indulge in the contemplation of nature!

Up the creek the Mergansers proceed, washing their bodies by short plunges, and splashing up the water about them. Then they plume themselves, and anoint their feathers, now and then emitting a low grunting note of pleasure. And now they dive in search of minnows, which they find in abundance, and which no doubt prove delicious food to the hungry travellers. 

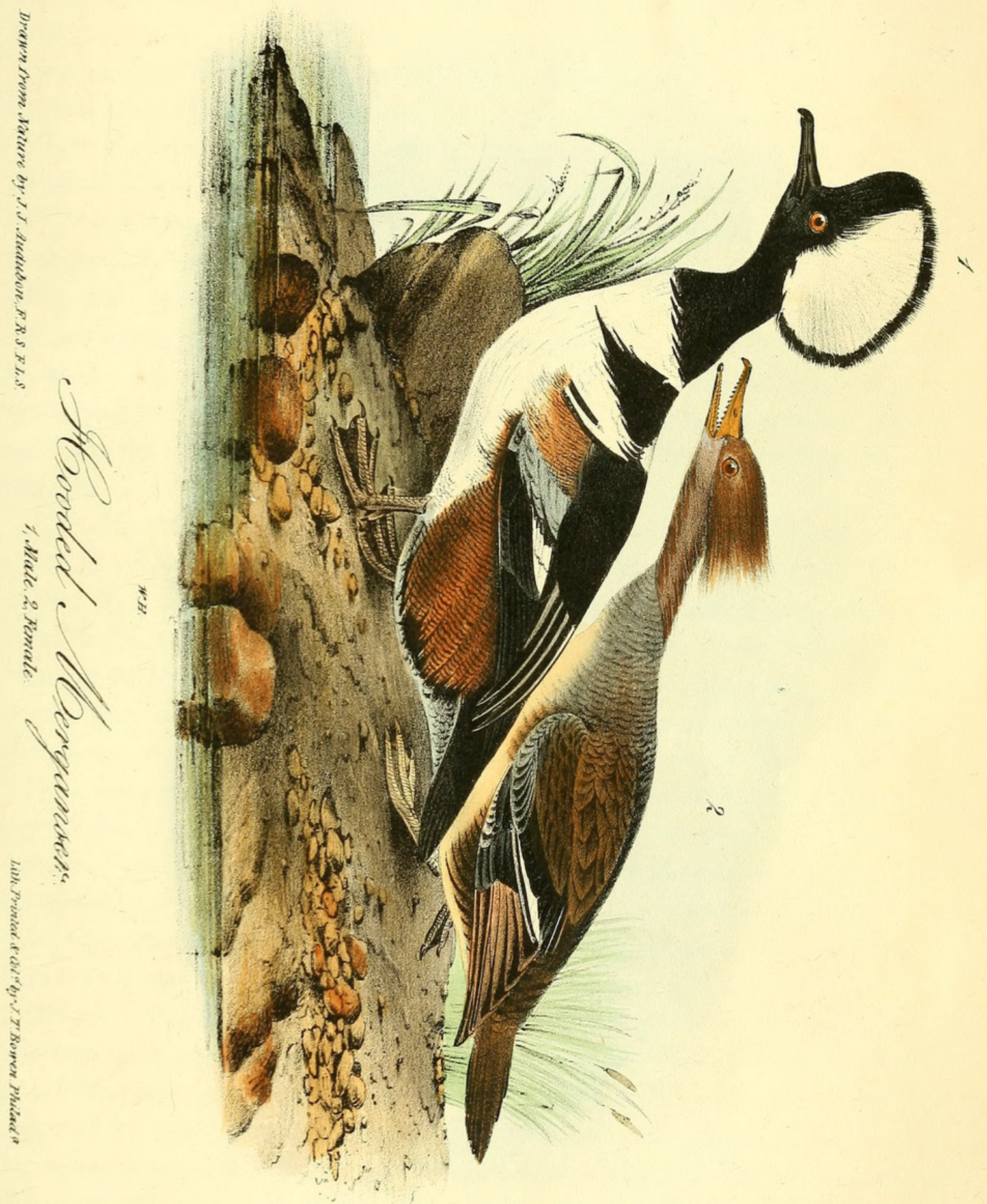

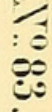

$\frac{5}{ \pm 0}$ 
$$
\text { - }
$$ 
At length, having satisfied their appetite, they rise on wing, fly low over the creek with almost incredible velocity, return to the broad stream, rove along its margin until they meet with a clean sand-beach, where they alight, and where, secure from danger, they repose until the return of day. A sly racoon may, when in search of mussels, chance to meet with the sleeping birds, and surprise one of them; but this rarely happens, for they are as wary and vigilant as their enemy is cunning, and were the prowler to depend upon Hooded Mergansers for food, he would be lean enough.

This bird ranges throughout the United States during winter, content with the food it meets with in the bays and estuaries of the eastern coast, and on the inland streams. The dam of the Pennsylvania miller is as agreeable to it as that of the Carolina rice-planter. The Lehigh and Brandywine creek have their fishes, as well as the waters of Bear Grass or Bayou Sara. Nay, the numerous streams and pools of the interior of the Floridas are resorted to by this species, and there I have found them full of life and gaiety, as well as on the Missouri, and on our great lakes. When the weather proves too cold for them, they move southwards, many of them removing towards Mexico.

The Hooded Merganser is a most expert diver, and so vigilant that at times it escapes even from the best percussion gun. As to shooting at it with a flint lock, you may save yourself the trouble unless you prevent it from seeing the flash of the pan. If you wound one, never follow it: the bird, when its strength is almost exhausted, immerses its body, raises the point of its bill above the surface, and in this manner makes its way among the plants, until finding some safe retreat along the shore, it betakes itself to it, and there remains, so that you may search for it in vain, unless you have a good dog. Even on wing it is not easily shot. If on a creek ever so narrow, it will fly directly towards its mouth, although you may be standing knee-deep in the middle. It comes up like a ball, rises and passes over head with astonishing speed, and if you shoot at it, do not calculate upon a hit. You may guess how many one may shoot in a day.

When I removed from Pennsylvania to Kentucky, the Hooded Merganser was not uncommon in the neighbourhood of Louisville during summer, and I told Wilson so. On several occasions I caught the young with a partridge net; and let me assure you, reader, that they are not yellow, as is alleged by some writers, but very dark brown. Even when feathered they retain the same colour until the beginning of August, when they gradually change it for the dress of the adult female.

Like all the rest of the tribe, which, when far north, for the want of hollow trees, breed on the moss or ground, the Hooded Mergansers that remain with us nestle in the same kind of holes or hollows as the Wood 
Duck; at least I have found their nests in such situations seven or eight times, although I never saw one of them alight on the branch of a tree, as the birds just mentioned are wont to do. They dive as it were directly into their wooden burrows, where, on a few dried weeds and feathers of different kinds, with a small quantity of down from the breast of the female, the eggs are deposited. They are from five to eight, measure one inch and threefourths by one and three-eighths, and in other respects perfectly resemble those of the Red-breasted Merganser.

The young, like those of the Wood Duck, are conveyed to the water by their mother, who carries them gently in her bill; for the male takes no part in providing for his offspring, but abandons his mate as soon as incubation has commenced. The affectionate mother leads her young among the tall rank grasses which fill the shallow pools or the borders of creeks, and teaches them to procure snails, tadpoles, and insects. The eggs are laid in May, and the young are out some time in June. On two occasions the parents would not abandon the young, although I expected that the noises which I made would have induced them to do so: they both followed their offspring into the net which I had set for them. The young all died in two days, when I restored the old birds to liberty.

The Hooded Merganser, as well as all the other species with which I am acquainted, moves with ease on the ground, nay, even runs with speed. Those which leave the United States, take their departure from the first of March to the middle of May; and I am induced to believe that probably one-third of them tarry for the purpose of breeding on the margins of several of our great lakes. When migrating, they fly at a great height, in small loose flocks, without any regard to order. Their notes consist of a kind of rough grunt, variously modulated, but by no means musical, and resembling the syllables croo, croo, crooh. The female repeats it six or seven times in succession, when she sees her young in danger. The same noise is made by the male, either when courting on the water, or as he passes on wing near the hole where the female is laying one of her eggs.

The males do not acquire the full beauty of their plumage until the third spring, but resemble the females for the first year. In the course of the second, the crest becomes more developed, and the white and black markings about the head and body are more distinct. The third spring they are complete, such as you see the bird represented in the plate.

Dr. Bachman has favoured me with the following note respecting this species:- "On the 19th April, 1838, at the plantation of Major Porches, on the Santee river, in South Carolina, I obtained an old female Merganser and her five young ones, the latter apparently from two to three weeks old. They were in a very small pond, and could not be driven from it. As we 
approached, the female sunk deep into the water, exhibiting only a very small portion of her back above the surface, and swimming with neck outstretched and low along the water. In endeavouring to drive the young to the high grounds, for the purpose of capturing them, they all dived in various directions, like Grebes. On conversing with an overseer, on the following day, he mentioned to me that he had on the previous week obtained several of the young in order to domesticate them, but having neglected to feed them on animal food they had all died. On the following day I met with two other broods, each of five, and was also shewn a cypress tree (Cupressus disticha) in the hollow of which a pair had been breeding during the present season. As far as I could learn, they breed in similar situations with the Summer Duck (Anas Sponsa), although generally a little earlier. They were all peculiarly marked with two white spots behind the wings on the back.

In an adult male, the width of the mouth is $7 \frac{1}{2}$ twelfths; the palate is flat, as is the-anterior part of the roof of the mouth, on which are two longitudinal series of slender oblique lamellæ, besides the prominent tooth-like plates of the margins, of which there are 33 on the upper and about 40 on the lower mandible, on each side. Tongue $1 \frac{1}{2}$ inches long, and of the same form as in the other species. Esophagus $7 \frac{1}{4}$ inches long, 1 inch in width in the greater part of its extent, 1 inch 2 twelfths within the thorax. The stomach is a gizzard of moderate strength, $1 \frac{1}{2}$ inches long, $1 \frac{1}{3}$ inches in breadth; its lateral muscles large, being 7 twelfths in thickness; the epithelium dense, tough, and forming two flat grinding surfaces. The proventricular glands are very small, forming a belt $1 \frac{1}{4}$ inches in breadth. The intestine is 51 inches long, its width from $3 \frac{1}{2}$ twelfths to $2 \frac{3}{4}$ twelfths; the cœca 9 twelfths long, 2 twelfths wide, 3 inches from the extremity; the rectum 5 twelfths wide, forming at the end a globular cloaca, 1 inch in width. Lobes of the liver nearly equal, $2 \frac{1}{4}$ inches in length; gall-bladder $\frac{1}{2}$ inch long.

Trachea $6 \frac{1}{4}$ inches long, much flattened, for 3 inches diminishing from $3 \frac{1}{2}$ twelfths to $2 \frac{1}{2}$ twelfths, then enlarging to $4 \frac{1}{2}$ twelfths; from this place to the tympanum it is of a trigonal form, with an acute carnia anteriorly, and the rings are widely separated. There are 102 rings, besides 8 which are united and form part of the tympanum, which is of an irregular form, projecting anteriorly with a rounded bulge, and dilated on the left side, its greatest breadth 9 twelfths. The bronchi are of moderate length, the left with 32, the right with 26 half rings. The muscles as in the other species; the contractor muscles exceedingly large at the upper part. 
Mergus cucullatus, Hooded Merganser, Swains. and Rich. F. Bor. Amer., vol. ii. p. 463.

Hooded Merganser, Nutt. Man., vol. ii. p. 465.

Hooded Merganser, Mergus cucullatus, Aud. Orn. Biog., vol. iii. p. 246; vol. iv. p. 619.

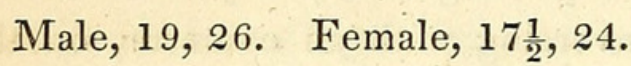

Breeds sparingly in South Carolina, along the Mississippi, Ohio, and the Great Lakes, as well as farther northward. Abundant, during autumn and winter, on all the western and southern waters; rarer in the Middle Atlantic Districts.

\section{Adult Male.}

Bill about the length of the head, straight, somewhat cylindrical, deeper than broad at the base. Upper mandible with the dorsal outline sloping gently to the middle, then straight, along the unguis curved, the ridge broad at the base, then convex, the sides sloping at the base, convex towards the end, the edges serrated beneath, with twenty-five tooth-like lamellæ directed backwards, the unguis oblong, much curved, rounded at the end. Nasal groove oblong, sub-basal, filled by a soft membrane; nostrils linear-elliptical, sub-medial, direct, pervious. Lower mandible with the angle very narrow and extended to the roundish unguis, the sides rounded, with a long narrow groove, the edges with about twenty-five lamellæ.

Head of moderate size, compressed, oblong. Neck rather short, body full and depressed. Wings small. Feet placed far behind, extremely short; tibia bare for a short space above the joint; tarsus extremely short, compressed, anteriorly covered with scutella, and another row on the lower half externally, the sides reticulate. Hind toe very small, with an inferior free membrane; anterior toes double the length of the tarsus; second shorter than fourth, which is nearly as long as the third, all connected by reticulated webs, of which the outer is deeply cut; the outer toe slightly margined, the inner with a broad marginal membrane. Claws short, considerably curved, compressed, acute, that of the middle toe with a thin inner edge.

Plumage on the upper parts strong and imbricated, on the lower blended and glossed; on the head and neck soft and blended, the feathers of the upper part of the head elongated and capable of being erected into a long compressed rounded crest, those of the shoulders very broad and elongated. Wings very short, small, curved, and pointed; primaries narrow, tapering, the first scarcely shorter than second, the rest rapidly graduated; secondaries short, narrow, rounded, the inner elongated and tapering. Tail short, graduated, of sixteen rounded feathers.

Bill black. Iris yellow. Feet yellowish-brown; claws dusky. Upper part of the head, back, smaller wing-coverts, quills and tail, brownish-black; sides of the head, upper half of the neck all round, the broad extremities of 
the large feathers on the shoulders, the scapulars, inner secondaries, and larger wing-coverts, greenish-black. A broad patch of white behind the eye, very conspicuous in the erected crest. Lower part of neck and breast also white, as are the speculum and the central part of the inner secondaries. Sides beautifully marked with undulated transverse lines of yellowish-brown and brownish-black; lower tail-coverts whitish, similarly undulated.

Length to end of tail 19 inches, to end of wings $16 \frac{3}{4}$, to end of claws 18 ; extent of wings 26 ; wing from flexure $7 \frac{1}{2}$; tail 4 ; bill along the ridge $1 \frac{1}{1} \frac{1}{2}$, along the edge of lower mandible $1 \frac{3}{4}$; tarsus $1 \frac{1}{4}$, middle toe $1 \frac{9 \frac{1}{2}}{12}$, its claw $\frac{1}{4}$. Weight $1 \mathrm{lb} .7 \mathrm{oz}$.

\section{Adult Female.}

The female is much smaller than the male. The crest is smaller and of a looser texture; the feathers of the shoulders not so large; those of the sides shorter and more compact. The bill is brownish-black towards the end and along the ridge, orange towards the base. The upper part of the head, including the crest, yellowish-brown; chin whitish, upper part of neck and sides of the head greyish-brown. The general colour of the back, upper surface of wings, tail, and sides, is blackish-brown, the feathers edged with paler, the edgings of the fore part of the back and shoulders larger and pale greyish-brown; speculum greyish-white; breast and abdomen pale yellowishbrown.

Length to end of tail $17 \frac{1}{2}$ inches, to end of claws $16 \frac{1}{2}$; extent of wings 24 . Weight $1 \mathrm{lb}$.

The young resemble the female. The young males after their first moult still resemble the female, but have the speculum and lower parts pure white. 

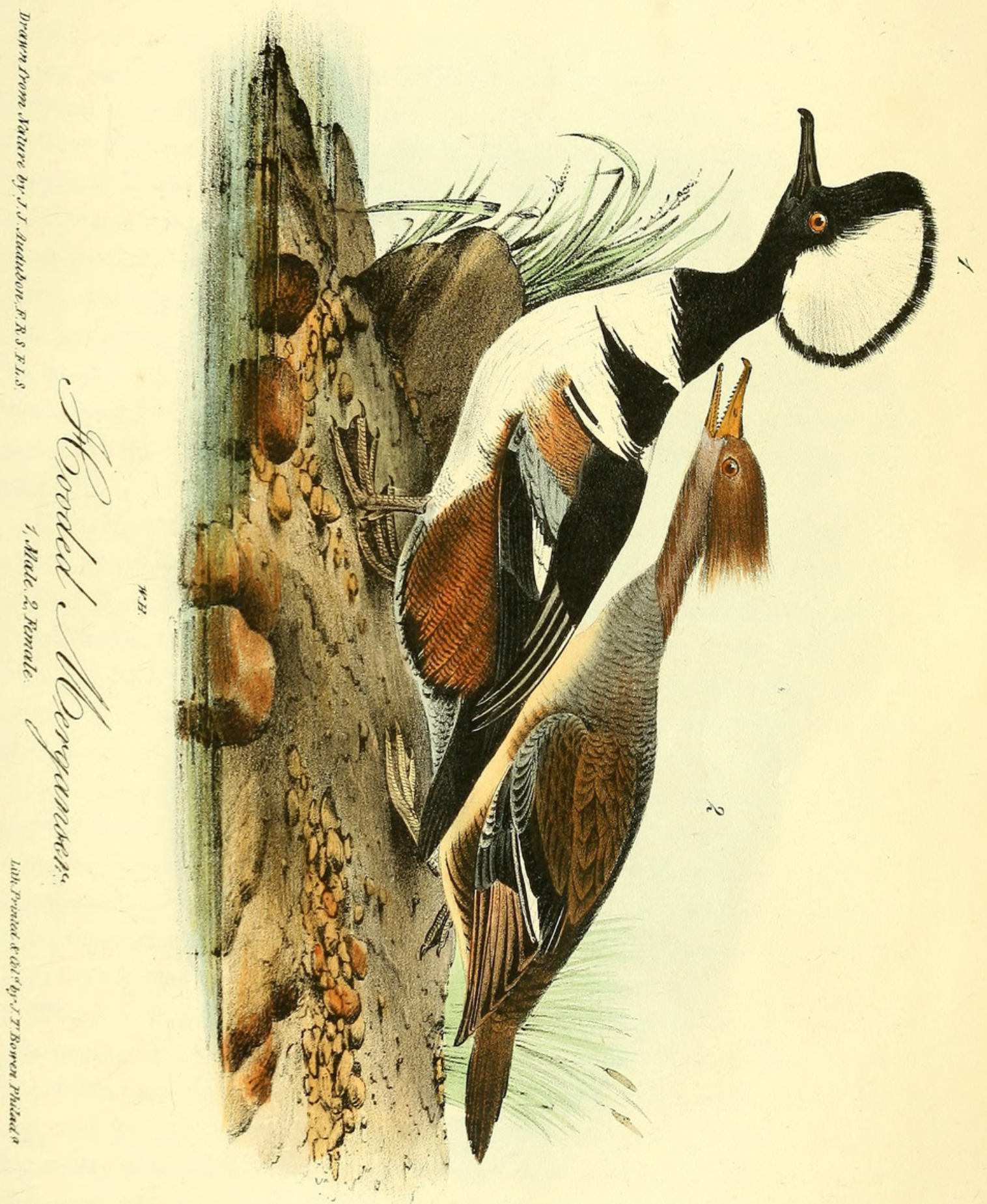

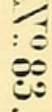

$\frac{5}{ \pm 0}$ 


\section{$2 \mathrm{BHL}$ Biodiversity Heritage Library}

Audubon, John James. 1843. "The Hooded Merganser, Mergus cucullatus, Linn. [PI. 413]." The birds of America : from drawings made in the United States and their territories 6, 402-407. https://doi.org/10.5962/p.319526.

View This Item Online: https://www.biodiversitylibrary.org/item/124857

DOI: https://doi.org/10.5962/p.319526

Permalink: https://www.biodiversitylibrary.org/partpdf/319526

\section{Holding Institution}

Smithsonian Libraries

\section{Sponsored by}

Biodiversity Heritage Library

\section{Copyright \& Reuse}

Copyright Status: NOT_IN_COPYRIGHT

This document was created from content at the Biodiversity Heritage Library, the world's largest open access digital library for biodiversity literature and archives. Visit BHL at https://www.biodiversitylibrary.org. 